\title{
MINIREVIEW
}

\section{Next generation tau models in Alzheimer's disease research - virus based gene delivery systems}

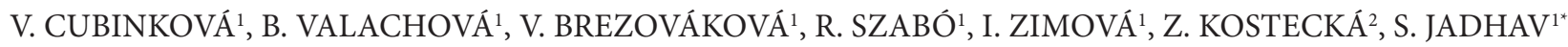 \\ ${ }^{1}$ Institute of Neuroimmunology Slovak Academy of Sciences, Centre of Excellence for Alzheimer's Disease and Related Disorders, \\ Dúbravská cesta 9, 84510 Bratislava, Slovak Republic; ${ }^{2}$ University of Veterinary Medicine and Pharmacy, 04181 Košice, \\ Slovak Republic
}

Received May 17, 2016; accepted July 21, 2016

\begin{abstract}
Summary. - Alzheimer's disease (AD) the most common form of dementia is characterized by cognitive decline and progressive loss of neurons in the central nervous system. Despite huge scientific progress, there are only few animal models that recapitulate at least majority of the AD pathology and related symptomatology. Therefore, alternative methods to develop animal models for neurodegenerative diseases are constantly explored. Recently, recombinant adeno-associated viruses (AAVs) are widely used viral vectors in development of novel models for neurodegenerative diseases. AAV vectors expressing full length, mutant or truncated forms of tau demonstrate early and robust pathology characterized by AT8 positivity, NFT formation, motor and cognitive deficits. Furthermore, AAVs have been used in expression of tau in amyloid rodent models thus developing both lesions of amyloid and tau therefore recapitulating AD like features. Major advantage of AAV as a delivery system is the site specific expression of tau, mostly in hippocampus and cortex, and thus elimination of unwanted ectopic transgene expression. These novel models may help in better understanding of AD etiopathogenesis and provide a platform for development and testing of disease modifying drugs in preclinical efficacy studies.
\end{abstract}

Keywords: adeno-associated viral vector; Alzheimer's disease; transgenic models; tau; tauopathy

\section{Contents:}

1. Introduction

2. Adeno-associated virus as a delivery system for creation of novel transgenic models

3. Recombinant AAV vectors in investigating early stages of Alzheimer's disease

4. Summary and concluding remarks

${ }^{*}$ Corresponding author. E-mail:santosh.jadhav@savba.sk; phone: +412-2-5478-8100.

Abbreviations: $\mathrm{AAV}(\mathrm{s})=$ adeno-associated virus(es); $\mathrm{AD}=$ Alzheimer's disease; $\mathrm{CBA}=$ cytomegalovirus/chicken $\beta$-actin promoter; $\mathrm{CNS}=$ central nervous system; $\mathrm{EC}=$ entorhinal cortex; $\mathrm{NFT}=$ localized neurofibrillary tangles; WPRE = woodchuck hepatitis virus post-translational regulatory element; $4 \mathrm{R}$ tau $=$ tau with 4 repeat

\section{Introduction}

Human neurodegenerative diseases represent a group of disorders characterized by progressive dysfunction of the nervous system. Alzheimer's disease (AD) is the most common neurodegenerative disorder demonstrating memory impairment and cognitive decline, progressive impairment of daily activities and various neuropsychiatric symptoms (Cummings, 2004; Selkoe, 2011; Caselli et al., 2006). The manifestation of the disease is characterized by loss of neuronal plasticity (Arendt, 2001), synapse loss (Masliah et al., 1989, 1992), neuronal loss (Padurariu et al., 2012) and neurodegeneration (Masliah et al., 1996). The main neuropathological features of AD represent intracellularly localized neurofibrillary tangles (NFT's) composed of tau protein and extracellular accumulation of amyloid $\beta$ plaques 
in certain brain areas. Interestingly, the NFT's and amyloid $\beta$ plaques pathology are distributed in different brain areas in AD brain (Braak and Braak, 1991; Delacourte et al., 2002) suggesting non-overlapping manifestation of the two lesions. However, evidences suggest a stronger correlation between tau pathology and AD neurodegeneration (Falke et al., 2003; Ingelsson et al., 2004; Nelson et al., 2012). Relationship between regional distribution of phosphorylated tau and clinical signs indicates close relationship between tau and disease manifestation in AD (Braak and Braak, 1991), thus signifying that tau inclusions in $\mathrm{AD}$ brain modulate the clinical symptoms of the disease. This suggests that tau protein represents one of the main driving forces in $\mathrm{AD}$ neurodegeneration.

The research on molecular mechanisms of $\mathrm{AD}$ is especially complicated mainly due to different postmortem delays of collected brain tissues. Nervous tissue acquired from humans is fragile, biochemically unstable and affected by treatment, as well as other eventual neurologic impairments. Moreover, these samples are obtained usually from individuals in terminal stages of the disease, thus disabling investigation of ontogeny. Besides, these individuals may suffer from several other comorbidities, including inflammation-related diseases that might significantly affect postmortem examination. In addition, relatively high inter-individual variability, based on genetic and environmental factors, complicate the elucidation of $\mathrm{AD}$ pathogenesis. Another limitation is that the tissue obtained from the patients with neurodegenerative diseases does not allow exploring the progression or monitoring the development of the disease (Mason et al., 2013; Nasrallah and Dubroff, 2013).

Studies based on animal models enable us to evaluate molecular mechanisms of the disease and correlate them with clinical features and behavioral changes. Research utilizing available models of $\mathrm{AD}$ facilitates continual progress in our understanding of AD etiopathogenesis (Balmus et al., 2015; Simons, 2008). Currently used tau transgenic models express mostly mutated forms of tau protein. Even though these models develop certain features of AD-like pathology, they only partially mimic the human neurodegenerative disorder (Citron, 2010; Platt et al., 2013). Moreover, it is uncertain as to which extent the pathology in these rodents reflects the pathology in $\mathrm{AD}$ patients. Despite above mentioned limitations, animal models allow us to study hypothesis related to $\mathrm{AD}$ pathogenesis, and to test properties of new drugs designed for AD treatment (Shineman et al., 2011). Recent advances in development of transgenic animals have enabled the creation of rodent models that reproduce several aspects of human tauopathies (Bugos et al., 2009). Besides, alternate methods to generate animal models for neurodegenerative diseases are being constantly developed and investigated for better understanding of the disease pathogenesis.

\section{Adeno-associated virus as a delivery system for creation of novel transgenic models}

Vector based models have currently been widely used to study human diseases due to their high regional specificity and effectivity. Vector driven models are novel components that imitate slow disease progression (Klein et al., 2005). In particular the recombinant AAV vector driven expression of misfolded proteins has emerged as a promising tool to study the disease pathogenesis of numerous neurodegenerative disorders (Kirik et al., 2002; Lo Bianco et al., 2002; Kirik and Björklund, 2003; Jaworski et al., 2010a; Lathuilière et al., 2012). Wild-type AAVs or adeno satellite viruses are a replication-defective, non-pathogenic single-stranded DNA viruses classified under the family Parvoviridae and the genus Dependoparvovirus. They require helper virus particles such as adeno virus or herpes simplex virus for infection and replication (Daya and Berns, 2008). However, recombinant AAVs are infectious, but lack virulency and thus provide a platform for sustainable transgene expression in several animal models (Li et al., 2003; Wu et al., 2006). Recombinant AAVs offer broad range of infectious properties that target different cell types and mechanisms in rodents and humans (Bourdenx et al., 2014; Murlidharan et al., 2014; Shevtsova et al., 2005).

Thirteen different serotypes of AAVs and their different tropism have been currently well defined (Handa et al., 2000, Gao et al., 2002, 2005; Cearley and Wolfe, 2006; Zincarelli et al., 2008; Aschauer et al., 2013). The AAV serotypes vary in their origin (Wu et al., 2006), genome sequence, capsid protein (Choi et al., 2005; van Vliet et al., 2008), transduction properties based on proteoglycan binding and glycan modifications (Summerford and Samulski, 1998; Walters et al., 2001; Nonnenmacher and Weber, 2012; Holehonnur et al., 2014; Murlidharan et al., 2014; Table 1) and efficiency of transgene expression (Gao et al., 2002). Mainly in the central nervous system, the AAV serotypes differentially transduce and express proteins, and also vary in their mechanisms of axonal transport (Salegio et al., 2013; Aschauer et al., 2013; Table 1). It is yet unknown if the duration and variable expression in protein levels is attributed to the variable domains of the capsid protein in the AAV serotypes (Zincarelli et al., 2008). Nevertheless, several recombinant AAV vectors are being constantly developed that are better engineered to provide efficient and stronger expression of proteins (Gao et al., 2005; Daya and Berns, 2008).

AAV based neurodegenerative models were initially developed using well characterized AAV2 serotype (Choi et al., 2005; Wu et al., 2006). AAV2 serotype expressing P301L - 4R2N tau (tau with 4 repeat and 2 inserts) under different promoters showed variable expression profile in primary neurons (Klein et al., 2004; Table 2). Tau expression (pTau-W $\mathrm{AAV}$ ) in vitro was observed using AAV2 viral vectors con- 


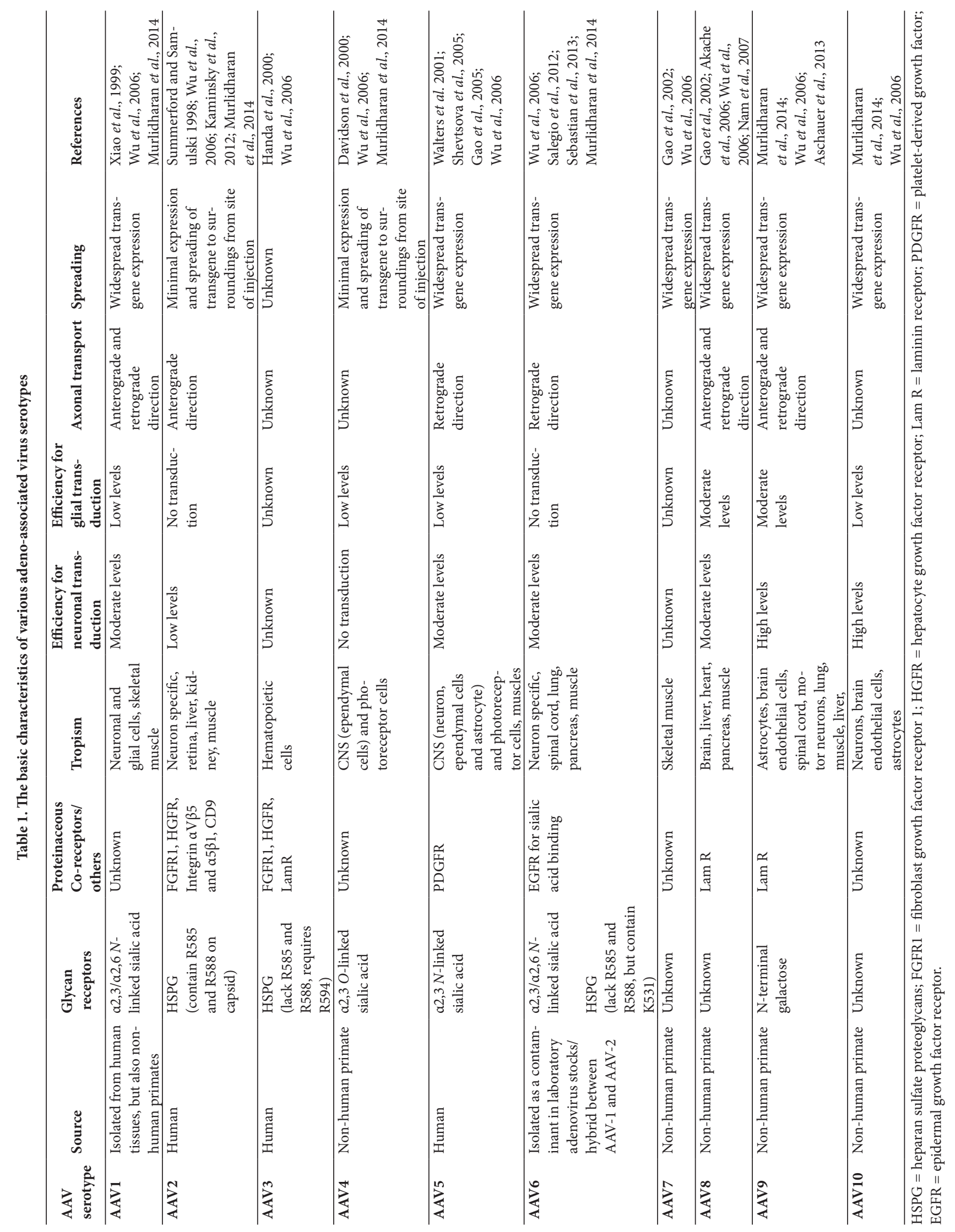


taining woodchuck hepatitis virus post-translational regulatory element (WPRE) and hybrid cytomegalovirus/chicken $\beta$-actin promoter (CBA), but not under CBA promoter alone (pCB-Tau AAV). Although, mild expression of tau was observed in vivo using CBA promoter, pTau-W AAV with dual promoter (WPRE and CBA) showed overt expression of P301L tau and abundance in Gallyas and AT100 positivity in neurons around the injected site. The animals showed behavioral deficits as early as 5 days post injection (Klein et al., 2004; Table 2). Furthermore, immune-electron micrographs confirmed the presence of tau protein in intracellular filament deposits in these neurons. Besides, injection of AAV2 tau vectors produced tau-positive dystrophic neurites with amyloid core similar to AD in PS1/APP double transgenic mice suggesting AAV vectors can be used to study multiple lesions in coherence in humanized models.

AAV8 serotype is considered to be one of the most potent serotype in gene delivery to the brain (Klein et al., 2006; Table 2). AAV8 demonstrated stronger transgenic expression in rat neurons, both in vitro and in vivo. Similar to AAV2, the AAV8 transduced cultured astrocytes but not the astrocytes in the brain (Klein et al., 2006). Injection of two doses of AAV8 vector expressing P301L mutated tau protein resulted in 74-78\% of neurodegeneration in substantia nigra. This effect was not observed using AAV5 vector strain. Furthermore, the AAV8 tau was more efficient in inducing neuronal loss when compared to AAV2 tau or AAV5 tau. AAV8 tau vector resulted in significant loss of neurons than AAV2 tau by about 74-78\% loss of dopamine neurons (Klein et al., 2006). This profound neuronal loss also caused significant amphetamine stimulated rotational behavior in these animals.

AAV9 and/or AAV 10 vectors also show early expression of tau accompanied by robust loss of nigrostriatal system when compared to AAV2 tau vector, mainly in the form of dopaminergic and GABAergic neuron loss (Klein et al., 2008, 2009). This effect was not observed using equal doses of green fluorescent protein (GFP) or alpha-synuclein vectors suggesting that the pathological effect is highly specific to misfolded tau neurotoxicity. Expression of AAV9 P301L tau in hippocampus impaired spatial memory and learning (Mustroph et al., 2012). Interestingly, gliosis was also observed at the sites of injection. Based on these findings, the AAV8, AAV9 and AAV10 serotypes display several advantages for development of novel tau animal models (Klein et al., 2008, 2009).

Tau hyperphosphorylation and somatodendritic mislocalization, a classical hallmark of tauopathy, was observed in AAV6 serotype carrying wildtype tau or P301S tau form. This was accompanied by impairment of motor function in these models. These effects were absent in rodents injected with AAV6 tau harboring aggregation deficient mutation at I277P/ I308P (Lathuilière et al., 2013). Dassie et al. (2013) generated AAV6 serotype carrying mutant forms of tau (P301L and 3PO tau) to study the interaction of tau and $\beta$-amyloid pathology. They observed abnormal tau phosphorylation in dystrophic neurites in close association with amyloid plaques (Dassie et al., 2013). The same was previously observed by Tackenberg and Brandt (2009), and they showed that amyloid $\beta$ alone was not neurotoxic but can induce toxicity through phosphorylation of tau. AAV 1/2 serotype expressing wildtype 4R tau or P301L tau resulted in near complete loss of pyramidal neurons in CA1/2 region and adjacent cortical layers (Jaworski et al., 2009, 2010b). Temporal progression of the disease was accompanied by marked tau hyperphosphorylation in several $\mathrm{AD}$ associated phospho-sites and tau aggregation. Microgliosis was noted during onset and active progression of the disease implying closer association between tau neurodegeneration and microgliosis. Interestingly AAV1/2 expressing truncated $4 \mathrm{R}$ tau at aa 255 , thereby lacking microtubule domain, failed to induce neurodegeneration or microgliosis when compared to full length counterparts (Jaworski et al., 2009). However, unlike full length tau which showed somatodendritic localization, the tau 255 was localized in the neuronal soma and was partially phosphorylated at AT8 and AT270 epitopes. These findings are in line with our studies showing that microtubule binding domain of tau plays a crucial role in neurodegeneration. Our transgenic models expressing human truncated tau with microtubule binding domain (aa 151-391) shows robust tau pathology in the cortex and brain stem (Zilka et al., 2006; Filipcik et al., 2012). Additionally, this study also establishes the role of truncated tau and the microtubule binding domain in $\mathrm{AD}$ disease pathogenesis.

\section{Recombinant AAV vectors in investigating early stages of Alzheimer's disease}

Mimicking early stages of $\mathrm{AD}$ disease progression has been the primary goal of many researchers to understand the ontogeny of the disease. In $\mathrm{AD}$, the tau pathology initially manifests in the entorhinal cortex (EC) and spreads to the synaptically connected neural circuits in the hippocampus and cortex (Braak and Braak, 1991). In recent years, AAV animal models have been effectively used to develop and successfully imitate the early stages of disease progression. For example, intra-entorhinal delivery of hybrid AAV2/9 viral vector with synapsin I promoter expressing tau with P301L mutation induced expression in neurons in the ECII layer and associated dendritic processes following the perforant pathway, the hippocampal fissure and the outer molecular layer in dentate gyrus (Siman et al., 2013; Table 2). The model developed several features of $\mathrm{AD}$ like tauopathy mimicking early Braak stage I. More importantly, the model was also able to simulate the trans-synaptic spread of tau since injection of AAV particles in the EC showed spread of tau pathology to the dentate gyrus and mossy fibers pathways 
Table 2. List of different serotypes of recombinant adeno-associated viruses expressing various tau isoforms, their sites of injection, promoter used and pathology developed

\begin{tabular}{|c|c|c|c|c|c|c|}
\hline $\begin{array}{l}\text { AAV } \\
\text { serotype }\end{array}$ & Promoter & Injection site & Tau form & Mice injected & Pathology & Reference \\
\hline AAV1 & $\begin{array}{l}\text { CBA with } \\
\text { WPRE }\end{array}$ & $\begin{array}{l}\text { Lateral ventricles: } \\
\text { (posterior to bregma } \\
\text { and } \mathrm{L}: 2 \mathrm{~mm} \text { lateral } \\
\text { to the midline) } \\
\text { bilateral }\end{array}$ & hTau P301L & C57Bl/6 mouse pups & $\begin{array}{l}\text { NFTs, neuropil threads, } \\
\text { dystrophic neurites, gliosis, } \\
\text { behavioral changes } \\
\text { synaptic abnormalities } \\
\text { hyperactivity, anxiety, deficits } \\
\text { in a contextual fear condi- } \\
\text { tioning }\end{array}$ & Cook et al., 2015 \\
\hline AAV2 & $\begin{array}{l}\text { CBA with } \\
\text { WPRE }\end{array}$ & $\begin{array}{l}\text { Substantia nigra } \\
\text { (AP: } 5.4 \mathrm{~mm}, \mathrm{~L}: 2.0 \\
\text { mm, DV: } 7.6 \mathrm{~mm} \text { ) } \\
\text { unilateral }\end{array}$ & hTau P301L & $\begin{array}{l}\text { Male Sprague-Dawley } \\
\text { rats } \\
\text { ( } 3 \text { months old) }\end{array}$ & $\begin{array}{l}\text { tau hyperphosphorylation, } \\
\text { loss of dopaminergic neurons } \\
\text { in substantia nigra, } \\
\text { motor deficit }\end{array}$ & Klein et al., 2005 \\
\hline \multirow[t]{3}{*}{ AAV2 } & \multirow[t]{3}{*}{$\begin{array}{l}\text { CBA with } \\
\text { WPRE }\end{array}$} & $\begin{array}{l}\text { Medial septum } \\
\text { (AP: } 0,7 \mathrm{~mm}, \mathrm{~L}: 0,2 \\
\text { mm, DV: } 7,0 \mathrm{~mm} \text { ) }\end{array}$ & \multirow[t]{3}{*}{ hTau P301L } & $\begin{array}{l}\text { Male Sprague-Dawley } \\
\text { rats } \\
\text { ( } 3 \text { months old) }\end{array}$ & $\begin{array}{l}\text { NFTs, Gallyas positive dys- } \\
\text { trophic neurites }\end{array}$ & \multirow[t]{3}{*}{ Klein et al., 2004} \\
\hline & & Hippocampus & & & & \\
\hline & & $\begin{array}{l}\text { (AP: } 2.1 \mathrm{~mm}, \mathrm{~L}: 1.2 \\
\mathrm{~mm}, \mathrm{DV}: 2.0 \mathrm{~mm}) \\
\text { unilateral }\end{array}$ & & $\begin{array}{l}\text { PS1/APP mice ( } 2 \text { month } \\
\text { old) }\end{array}$ & tau-immunoreactive neurites & \\
\hline \multirow[t]{2}{*}{ AAV2 } & \multirow[t]{2}{*}{ NA } & \multirow[t]{2}{*}{ NA } & htau 4R & \multirow[t]{2}{*}{ WT mice (13 months old) } & \multirow[t]{2}{*}{$\begin{array}{l}\text { tau fibrillary deposits } \\
\text { caspase activation }\end{array}$} & \multirow[t]{2}{*}{$\begin{array}{l}\text { de Calignon et al., } \\
2010\end{array}$} \\
\hline & & & $\Delta$ tau aa421 & & & \\
\hline rAAV2 & $\begin{array}{l}\text { CBA with } \\
\text { WPRE }\end{array}$ & $\begin{array}{l}\text { Entorhinal cortex } \\
\text { (AP: } 8.3 \mathrm{~mm}, \mathrm{~L}: 3.3 \\
\mathrm{~mm}, \\
\text { DV: } 6.0 \text { or } 5.0 \mathrm{~mm} \\
\text { and AP: } 8.8 \mathrm{~mm} \text {, } \\
\text { L: } 3.7 \mathrm{~mm}, \mathrm{DV}: 5.0 \\
\mathrm{~mm}) \\
\text { bilateral }\end{array}$ & hTau P301L & $\begin{array}{l}\text { Male Sprague-Dawley } \\
\text { rats (Approx } 90 \text { days) }\end{array}$ & $\begin{array}{l}\text { AT8 positive neurofibrillary } \\
\text { tangles in hippocampus, no } \\
\text { overt neuronal or synaptic } \\
\text { loss, } \\
\text { impaired spatial learning }\end{array}$ & Ramirez et al., 2011 \\
\hline \multirow[t]{3}{*}{ AAV6 } & \multirow[t]{3}{*}{ PGKP } & \multirow{3}{*}{$\begin{array}{l}\text { Entorhinal cortex } \\
\text { (AP: } 3.0 \mathrm{~mm}, \mathrm{~L}: 3.7 \\
\text { mm, DV: } 4.0 \mathrm{~mm} \text { ) } \\
\text { unilateral }\end{array}$} & hWT 4R0N & \multirow{3}{*}{$\begin{array}{l}\text { TASTPM mice } \\
\text { (hAPP695swe } \\
\text { and PS-1 } \\
\text { M146V) C57BL/6J mice }\end{array}$} & $\begin{array}{l}\text { loss of neurons only after } 8 \\
\text { months }\end{array}$ & \multirow[t]{3}{*}{ Dassie et al., 2013} \\
\hline & & & 3PO-tau & & age dependent loss in neurons & \\
\hline & & & $\begin{array}{l}\text { h Tau 4R0N P301S } \\
\text { (0N3R) }\end{array}$ & & $\begin{array}{l}\text { AT8, MC1 positive pyramidal } \\
\text { neurons and apical dendrites } \\
\text { working memory impairment }\end{array}$ & \\
\hline \multirow[t]{3}{*}{ AAV6 } & \multirow[t]{3}{*}{ NA } & \multirow[t]{3}{*}{$\begin{array}{l}\text { Lateral ventricles } \\
\text { bilateral }\end{array}$} & hWT 4R & \multirow[t]{3}{*}{ C57Bl/6 mouse pups } & $\begin{array}{l}\text { neuronal tau pathology } \\
\text { progressive motor deficit }\end{array}$ & \multirow[t]{3}{*}{$\begin{array}{l}\text { Lathuiliere et al., } \\
2013\end{array}$} \\
\hline & & & hTau P301S & & & \\
\hline & & & $\begin{array}{l}\text { Double mutated tau } \\
\text { I277P/I308P }\end{array}$ & & $\begin{array}{l}\text { no detectable motor pheno- } \\
\text { type }\end{array}$ & \\
\hline AAV8 & $\begin{array}{l}\text { CBA with } \\
\text { WPRE }\end{array}$ & $\begin{array}{l}\text { Hippocampus } \\
\text { (AP: } 3.6 \mathrm{~mm}, \mathrm{~L}: 2.0 \\
\text { mm, DV: } 3.5 \text { or } 2.8 \\
\text { mm) } \\
\text { Substantia nigra } \\
\text { (AP: } 5.3 \mathrm{~mm}, \mathrm{~L}: 2.1 \\
\text { mm, DV: } 7.6 \mathrm{~mm} \text { ) } \\
\text { unilateral }\end{array}$ & hTau P301L & $\begin{array}{l}\text { Male Sprague-Dawley } \\
\text { rats } \\
\text { ( } 3 \text { months old) }\end{array}$ & $\begin{array}{l}\text { loss of tyrosine hydroxylase } \\
\text { neurons and lesions in sub- } \\
\text { stantia nigra }\end{array}$ & Klein et al., 2006 \\
\hline
\end{tabular}


Table 2. (continue)

\begin{tabular}{|c|c|c|c|c|c|c|}
\hline $\begin{array}{l}\text { AAV } \\
\text { serotype }\end{array}$ & Promoter & Injection site & Tau form & Mice injected & Pathology & Reference \\
\hline AAV9 & $\begin{array}{l}\text { CBA with } \\
\text { WPRE }\end{array}$ & $\begin{array}{l}\text { Hippocampus } \\
\text { (AP: } 2.0 \mathrm{~mm}, \mathrm{~L}: 1.5 \\
\text { mm, DV: } 3.0 \mathrm{~mm} \text {; } \\
\text { and } \\
\text { AP: } 4.2 \mathrm{~mm}, \mathrm{~L}: 4.5 \\
\text { mm, DV: } 5.0 \mathrm{~mm} \text { ) } \\
\text { bilateral }\end{array}$ & hTau P301L & $\begin{array}{l}\text { Male Sprague-Dawley } \\
\text { rats } \\
\text { ( } 3 \text { months old })\end{array}$ & $\begin{array}{l}\text { hyperphosphorylated tau and } \\
\text { NFTs, neuronal loss in the } \\
\text { hippocampus }\end{array}$ & $\begin{array}{l}\text { Mustroph et al., } \\
2012\end{array}$ \\
\hline AAV9 & $\mathrm{CBA}$ & $\begin{array}{l}\text { Hippocampus } \\
\text { (AP: } 3.6 \mathrm{~mm}, \mathrm{~L}: 2.0 \\
\mathrm{~mm}, \\
\text { DV: } 3.5 \text { or } 2.8 \mathrm{~mm} \text { ) } \\
\text { bilateral }\end{array}$ & htau $4 \mathrm{R}$ & $\begin{array}{l}\text { Male Sprague-Dawley } \\
\text { rats }\end{array}$ & $\begin{array}{l}\text { no behavioral or neuronal } \\
\text { deficits }\end{array}$ & Dayton et al., 2012 \\
\hline AAV2 & CBA with & Substantia nigra & hTau P301L & Male Sprague-Dawley & loss of dopaminergic neu- & Klein et al., 2008 \\
\hline AAV8 & WPRE & (DV: $5.3 \mathrm{~mm}, \mathrm{~L}: 2.1$ & & rats & rons in substatia nigra pars & \\
\hline AAV9 & & $\mathrm{mm}, \mathrm{DV}: 7,6 \mathrm{~mm})$ & & (3 months old) & compacta & \\
\hline AAV10 & & bilateral & & & $\begin{array}{l}\text { degrees of DA loss: } \\
\text { AAV9=AAV10>AAV8>AAV2 }\end{array}$ & \\
\hline \multirow[t]{2}{*}{ AAV1/2 } & HSNP & $\begin{array}{l}\text { Hippocampus } \\
\text { (AP: } 1.94 \mathrm{~mm}, \mathrm{~L}: \\
1.4 \mathrm{~mm} \text { and DV: } 2.2 \\
\mathrm{~mm} \text { ) } \\
\text { unilateral }\end{array}$ & hTau P301L & Adult WT FVB/N mice & $\begin{array}{l}\text { degenerating and dystrophic } \\
\text { neurons with vacuolar struc- } \\
\text { tures, } \\
\text { neuroinflammation and oxi- } \\
\text { dative stress }\end{array}$ & Jaworski et al., 2009 \\
\hline & & & $\Delta$ tau aa 255 & & $\begin{array}{l}\text { no appreciable neurodegen- } \\
\text { eration } \\
\text { no microgliosis }\end{array}$ & \\
\hline \multirow[t]{2}{*}{ AAV $1 / 2$} & HSNP & $\begin{array}{l}\text { Hippocampus } \\
\text { (AP: } 1.94 \mathrm{~mm}, \mathrm{~L}: \\
1.4 \mathrm{~mm} \text { and DV: } 2.2 \\
\mathrm{~mm} \text { ) } \\
\text { unilateral }\end{array}$ & hTau P301L & $\begin{array}{l}\text { WT FVB/N mice }(3-4 \\
\text { months old) }\end{array}$ & $\begin{array}{l}\text { degenerating and dystrophic } \\
\text { neurons with vacuolar struc- } \\
\text { tures } \\
\text { dendritic deficits, oxidative } \\
\text { stress and neuroinflammation }\end{array}$ & Jaworski et al., 2011 \\
\hline & & & & $\begin{array}{l}\text { YFP- expressing trans- } \\
\text { genic mice }\end{array}$ & $\begin{array}{l}\text { decrease in dentritic spines } \\
\text { and degenerating neurons }\end{array}$ & \\
\hline AAV 2/6 & $\begin{array}{l}\text { PGKP } \\
\text { with } \\
\text { WPRE }\end{array}$ & $\begin{array}{l}\text { Perirhinal cortex } \\
\text { (AP:1.8 mm, L: } 4.2 \\
\text { mm, DV: } 4 \mathrm{~mm} \text { and } \\
\text { AP: } 3.2 \mathrm{~mm}, \mathrm{~L}: 4.1 \\
\text { mm, DV: } 3.8 \mathrm{~mm} \text { ) } \\
\text { bilateral }\end{array}$ & hTau P301S & Adult $\mathrm{C} 57 \mathrm{Bl} / 6$ mice & $\begin{array}{l}\text { tau hyperphosphorylation, } \\
\text { aggregation and neurodegen- } \\
\text { eration } \\
\text { deficit in synaptic transmis- } \\
\text { sion } \\
\text { severe object recognition } \\
\text { memory deficit }\end{array}$ & Yang et al., 2015 \\
\hline AAV $2 / 9$ & HSNP & $\begin{array}{l}\text { Hippocampus } \\
\text { (AP: } 4.0 \mathrm{~mm}, \mathrm{~L}: 4.5 \\
\text { mm, DV: } 2.9 \mathrm{~mm} \text { ) } \\
\text { unilateral }\end{array}$ & hTau P301L & $\begin{array}{l}\text { Male CD-1 } \\
\text { Mice (3-4 months old) }\end{array}$ & $\begin{array}{l}\text { postsynaptic spreading of tau } \\
\text { and loss of perforant pathway } \\
\text { synapses and neurons }\end{array}$ & Siman et al., 2013 \\
\hline
\end{tabular}

Htau = human tau; NA = not available; $\Delta$ tau = truncated tau; WPRE = woodchuck hepatitis virus post-translational regulatory element; HSNP = human synapsin 1 gene promoter; $\mathrm{CBA}=$ hybrid cytomegalovirus/chicken $\beta$-actin promoter; $\mathrm{PGKP}=$ phosphoglycerate kinase 1 promoter; $\mathrm{AP}=$ anteriorposterior; $\mathrm{L}=$ lateral, $\mathrm{DV}=$ dorsal-ventral. 
in the striatum lucidum and mossy fibers in the CA3 region. Tau hyperphosphorylation (AT8, pThr231) and aggregation was prominent in the EC. Likewise, Gallyas positive neurofibrillary tangles were observed in these animals in EC at 6 weeks post injection. Tau protein expression induced loss of the cells in the ECII by up to $81 \%$ and loss of synapses in the dentate gyrus and lateral perforant layer pathway in the outer molecular layer and molecular layer shank. Delineating the mechanisms of neuronal loss in these cells revealed cell loss by caspase mediated apoptosis. Similarly, caspase positive neurons were detected in Tg4510 mice or htau mice injected with AAV2 vector expressing full length tau 4R (de Calignon et al., 2010; Table 2). These evidences suggest that soluble tau triggers caspase activation in these neurons. Remarkably, caspase cleaved truncated tau at Asp421 was found in caspase positive neurons in these models. Moreover, expression of truncated tau at Asp421 using AAV2 in wild type mice showed Alz50 immuno-reactive neurons which were also positive for PHF1 and AT8 antibodies suggesting misfolded tau conformation in these neurons (de Calignon et al., 2010). Furthermore these results also propose that tau truncation was essential to induce tau misfolding and tau hyperphosphorylation.

Interestingly AAV2/6 serotype with synapsin-1 promoter expressing P301L tau injected in the medial EC developed tau pathology as early as 7 days post injection (Asai et al., 2015). The model also showed rapid progression of tau pathology to dentate granule cells. Notably, the expression of tau reduced the spike amplitude in these animals when compared to AAV-GFP group implying diminished excitability in the dentate gyrus. In addition, pharmacological depletion of microglia reduced AT8 positivity in the dentate gyrus suggesting the role of microglia in progression of tau pathology in $\mathrm{AD}$ and other tauopathies (Asai et al., 2015). Similarly, expression of human $4 \mathrm{R}$ tau (hWT4R) using AAV2/5 in EC also showed AT8 positivity and induced axonal fragmentation in the perforant pathway axons (Combs et al., 2016). These evidences suggest that precise and selective transduction of AAV serotypes can be used to mimic early $\mathrm{AD}$ disease pathogenesis.

Numerous other AAV-tau models have been developed under different genetic background (Table 2). Most of these models build up AT8 positivity (Klein et al., 2005; Ramirez et al., 2011; Dassie et al., 2013; Asai et al., 2015), neurofibrillary tangles (Klein et al., 2006; de Calignon et al., 2010; Ramirez et al., 2011), degenerating and dystropic neurites (Jaworski et al., 2009, 2011), motor impairment (Klein et al., 2008; Cook et al., 2015), synaptic deterioration (Jaworski et al., 2011; Siman et al., 2013; Yang et al., 2015; Cook et al., 2015) and loss of neurons (Klein et al., 2005, 2008; Jaworski et al., 2011; Mustroph et al., 2012; Dassie et al., 2013; Yang et al., 2015) implicating that AAV vectors can be used to generate rodent models in a short span of time which are efficient (transduction and level of expression) and imitate early and progressive pathological changes as in AD and other tauopathies.

\section{Summary and concluding remarks}

Recombinant AAV vectors are currently emerging as the preferred gene delivery vehicles for CNS (Manfredsson 2016). They provide efficient gene transfer, long-term transgene expression, minimal virulence, low immunogenicity (Heilbronn et al., 2010) and scalable manufacture for clinical applications. Despite huge scientific progress achieved in recent years, questions related to $\mathrm{AD}$ etiopathogenesis remain unanswered (Ballard et al., 2011). Recombinant AAV systems are currently the most efficient gene delivery vehicles to develop animal models for Alzheimer's disease and Parkinson's disease and are currently used in development for clinical interventions against numerous disorders (Combs et al., 2016). Choice of AAV serotypes along with site specific application allows accurate transduction of extraneous genes to cell type of choice.

There are several advantages of AAV vector models for Alzheimer's disease, including if not limited to: (1) development of pathological lesions that mimic early stages of tau pathology, (2) induction of a disease specific pathology in the different brain regions, (3) induction of tau pathology in specific neuronal subpopulations and in glial cells, (4) the ability to study the effect of multiple pathological lesions simultaneously, (5) the ability to introduce tau lesions in amyloid models, (6) expression can be induced at any stage of nervous system development, and finally, (7) AAV driven transgene expression is reproducible and pathological changes are observed within a shorter period of time.

What's more, the advent of newer recombinant AAV strains offers prospects for generation of animal models which reflect better pathology as in human neurodegenerative diseases. The AAV driven animal tau models may help to understand the mechanism/s of tau pathogenesis and provide opportunities for development of potential therapeutic approaches against Alzheimer's disease and other tauopathies.

Acknowledgement. The authors greatly thank Norbert Žilka and Peter Filipčík for revision of the manuscript. This work was supported by research grants APVV 14-0872, APVV-0677-12, EU structural fund 26240220046 and Axon Neuroscience.

\section{References}

Akache B, Grimm D, Pandey K, Yant SR, Xu H, Kay MA, J. Virol. 80, 9831-9836, 2006. https://doi.org/10.1128/JVI.00878-06 
Arendt T, Int. J. Dev. Neurosci. 19, 231-245, 2001. https://doi. org/10.1016/S0736-5748(01)00007-7

Asai H, Ikezu S, Tsunoda S, Medalla M, Luebke J, Haydar T, Wolozin B, Butovsky O, Kügler S, Ikezu T, Nat. Neurosci. 18, 1584-1593, 2015. https://doi.org/10.1038/nn.4132

Aschauer DF, Kreuz S, Rumpel S, PLoS One. 8, 2013.

Ballard C, Gauthier S, Corbett A, Brayne C, Aarsland D, Jones, Lancet. 377, 1019-1031, 2011. https://doi.org/10.1016/ S0140-6736(10)61349-9

Balmus IM, Ciobica A, Negura A, Negura L, Anton E, Psychiatr. Danub. 27, 338-345, 2015.

Bourdenx M, Dutheil N, Bezard E, Dehay B, Front. Mol. Neurosci. 7, 50, 2014. https://doi.org/10.3389/ fnmol.2014.00050

Braak H, Braak E, Acta Neuropathol. 82, 239-259, 1991. https:// doi.org/10.1007/BF00308809

Bugos O, Bhide M, Zilka N, Neurobiol. 29, 859-869, 2009.

Caselli RJ, Beach TG, Yaari R, Reiman EM, J. Clin. Psychiatry, 1784-1800, 2006. https://doi.org/10.4088/JCP.v67n1118

Cearley CN, Wolfe JH, Mol. Ther. 13, 528-537, 2006. https://doi. org/10.1016/j.ymthe.2005.11.015

Choi VW, McCarty DM, Samulski RJ, Curr. Gene Ther. 5, 299-310, 2005. https://doi.org/10.2174/1566523054064968

Citron M, Nat. Rev. Drug Discov. 9, 387-398, 2010. https://doi. org/10.1038/nrd2896

Combs B, Kneynsberg A, Kanaan NM, Methods Mol. Biol. 1382, 339-366, 2016. https://doi.org/10.1007/978-1-49393271-9 25

Cook C, Kang SS, Carlomagno Y, Lin WL, Yue M, Kurti A, Shinohara M, Jansen-West K, Perkerson E, Castanedes-Casey M, Rousseau L, Phillips V, Bu G, Dickson DW, Petrucelli L, Fryer JD, Hum. Mol. Genet. 24, 6198-6212, 2015. https://doi.org/10.1093/hmg/ddv336

Cummings JL, N. Engl. J. Med. 351, 56-67, 2004. https://doi. org/10.1056/NEJMra040223

Dassie E, Andrews MR, Bensadoun JC, Cacquevel M, Schneider BL, Aebischer P, Wouters FS, Richardson JC, Hussain I, Howlett DR, Spillantini MG, Fawcett JW, Neurobiol. Aging. 34, 1355-1368, 2013. https://doi.org/10.1016/j. neurobiolaging.2012.11.011

Davidson BL, Stein CS, Heth JA, Martins I, Kotin RM, Derksen TA, Zabner J, Ghodsi A, Chiorini JA, Proc. Natl. Acad. Sci. U S A. 97, 3428-3432, 2000. https://doi.org/10.1073/ pnas.97.7.3428

Daya S, Berns KI, Clin. Microbiol. Rev. 21, 583-593, 2008. https:// doi.org/10.1128/CMR.00008-08

Dayton RD, Wang DB, Cain CD, Schrott LM, Ramirez JJ, King MA, Klein RL, Exp. Neurol. 233, 807-814, 2012. https://doi. org/10.1016/j.expneurol.2011.12.002

de Calignon A, Fox LM, Pitstick R, Carlson GA, Bacskai BJ, SpiresJones TL, Hyman BT, Nature 464(7292), 1201-1204, 2010. https://doi.org/10.1038/nature08890

Delacourte A, Sergeant N, Champain D, Wattez A, Maurage CA, Lebert F, Pasquier F, David JP, Neurology. 59, 398-407, 2002. https://doi.org/10.1212/WNL.59.3.398

Falke E, Nissanov J, Mitchell TW, Bennett DA, Trojanowski JQ, Arnold SE, Am. J. Pathol. 163, 1615-1621, 2003. https:// doi.org/10.1016/S0002-9440(10)63518-3
Filipcik P, Zilka N, Bugos O, Kucerak J, Koson P, Novak P, Novak M, Neurobiol. Aging. 33, 1448-1456, 2012. https://doi. org/10.1016/j.neurobiolaging.2010.10.015

Gao G, Vandenberghe LH, Wilson JM, Curr. Gene Ther. 5, 285-297, 2005. https://doi.org/10.2174/1566523054065057

Gao GP, Alvira MR, Wang L, Calcedo R, Johnston J, Wilson JM, Proc. Natl. Acad. Sci. U S A. 99, 11854-11859, 2002. https://doi.org/10.1073/pnas.182412299

Handa A, Muramatsu S, Qiu J, Mizukami H, Brown KE, J. Gen. Virol. 81, 2077-2084, 2000. https://doi.org/10.1099/00221317-81-8-2077

Heilbronn R, Weger S, Handb. Exp. Pharmacol. 197, 143-170, 2010. https://doi.org/10.1007/978-3-642-00477-3 5

Holehonnur R, Luong JA, Chaturvedi D, Ho A, Lella SK, Hosek MP, Ploski, BMC Neurosci. 15, 2014.

Ingelsson M, Fukumoto H, Newell KL, Growdon JH, Hedley-Whyte ET, Frosch MP, Albert MS, Hyman BT, Irizarry MC, Neurology. 62, 925-993, 2004. https://doi.org/10.1212/01. WNL.0000115115.98960.37

Jaworski T, Dewachter I, Lechat B, Croes S, Termont A, Demedts D, Borghgraef P, Devijver H, Filipkowski RK, Kaczmarek L, Kügler S, Van Leuven F, PLoS One. 4, 2009.

Jaworski T, Kügler S, Van Leuven F, Int. J. Alzheimer Dis. 2010, 2010a.

Jaworski T, Dewachter I, Seymour CM, Borghgraef P, Devijver H, Kügler S, Van Leuven F, Biochim. Biophys. Acta. 1802(10), 808-818, 2010b. https://doi.org/10.1016/j. bbadis.2010.03.005

Jaworski T, Lechat B, Demedts D, Gielis L, Devijver H, Borghgraef P, Duimel H, Verheyen F, Kügler S, Van Leuven F, Am. J. Pathol. 179, 2001-2015, 2011. https://doi.org/10.1016/j. ajpath.2011.06.025

Kaminsky PM, Keiser NW, Yan Z, Lei-Butters DC, Engelhardt JF, Mol. Ther. 20, 972-983, 2012. https://doi.org/10.1038/ mt.2011.295

Kirik D, Björklund A, Trends Neurosci. 26, 386-392, 2003. https:// doi.org/10.1016/S0166-2236(03)00164-4

Kirik D, Rosenblad C, Burger C, Lundberg C, Johansen TE, Muzyczka N, Mandel RJ, Björklund A, J. Neurosci. 22, 2780-2791, 2002.

Klein RL, Lin WL, Dickson DW, Lewis J, Hutton M, Duff K, Meyer EM, King MA, Am. J. Pathol. 164, 347-353, 2004. https:// doi.org/10.1016/S0002-9440(10)63124-0

Klein RL, Dayton RD, Lin WL, Dickson DW, Neurobiol. Dis. 20, 64-73, 2005. https://doi.org/10.1016/j.nbd.2005.02.001

Klein RL, Dayton RD, Leidenheimer NJ, Jansen K, Golde TE, Zweig RM, Mol. Ther. 13, 517-527, 2006. https://doi. org/10.1016/j.ymthe.2005.10.008

Klein RL, Dayton RD, Tatom JB, Diaczynsky CG, Salvatore MF, Eur. J. Neurosci. 27, 1615-1625, 2008. https://doi. org/10.1111/j.1460-9568.2008.06161.x

Klein RL, Dayton RD, Terry TL, Vascoe C, Sunderland JJ, Tainter KH, Brain Res. 1259, 113-122, 2009. https://doi. org/10.1016/j.brainres.2009.01.063

Lathuilière A, Cacquevel M, Schneider B, Aebischer P, Alzheimer's \& Dementia: J. Alz. Association. 8, 2012.

Lathuilière A, Papin S, Cacquevel M, Paganetti P, Muhs A, Knott G, Schneider B, Aebischer P, Mol. Neurodeg. 8, 2013. 
Li J, Wang D, Qian S, Chen Z, Zhu T, Xiao X, Gene Ther. 10, 1807-1813, 2003. https://doi.org/10.1038/sj.gt.3302078

Lo Bianco C, Ridet JL, Schneider BL, Deglon N, Aebischer P, Proc. Natl. Acad. Sci. U S A. 99, 10813-10818, 2002. https://doi. org/10.1073/pnas.152339799

Manfredsson FP, Methods Mol. Biol. 1382, 3-18, 2016. https://doi. org/10.1007/978-1-4939-3271-9 1

Masliah E, Ellisman M, Carragher B, Mallory M, Young S, Hansen L, DeTeresa R, Terry RD, J. Neuropathol. Exp. Neurol. 51, 404-414, 1992. https://doi.org/10.1097/00005072199207000-00003

Masliah E, Iwai A, Mallory M, Uéda K, Saitoh T, Am. J. Pathol. 148, 201-210, 1996.

Masliah E, Terry RD, DeTeresa RM, Hansen LA, Neurosci. Lett. 103, 234-239, 1989. https://doi.org/10.1016/0304-3940(89)90582-X

Mason NS, Mathis CA, Klunk WE, J. Labelled Comp. Radiopharm. 56, 89-95, 2013. https://doi.org/10.1002/jlcr.2989

Murlidharan G, Samulski RJ, Asokan A, Front. Mol. Neurosci. 7, 2014.

Mustroph ML, King MA, Klein RL, Ramirez JJ, Behav. Brain Res. 233(1), 141-148, 2012. https://doi.org/10.1016/j. bbr.2012.04.034

Nam HJ, Lane MD, Padron E, Gurda B, McKenna R, Kohlbrenner E, Aslanidi G, Barry Byrne B, Muzyczka N, Zolotukhin S, Agbandje-McKenna M, J. Virol. 81, 12260-12271, 2007. https://doi.org/10.1128/JVI.01304-07

Nasrallah I, Dubroff J, Semin. Nucl. Med. 43, 449-461, 2013. https:// doi.org/10.1053/j.semnuclmed.2013.06.003

Nelson PT, Alafuzoff I, Bigio EH, Bouras C, Braak H, Cairns NJ, Castellani RJ, Crain BJ, Davies P, Del Tredici K, Duyckaerts C, Frosch MP, Haroutunian V, Hof PR, Hulette CM, Hyman BT, Iwatsubo T, Jellinger KA, Jicha GA, Kövari E, Kukull WA, Leverenz JB, Love S, Mackenzie IR, Mann DM, Masliah E, McKee AC, Montine TJ, Morris JC, Schneider JA, Sonnen JA, Thal DR, Trojanowski JQ, Troncoso JC, Wisniewski T, Woltjer RL, Beach TG, J. Neuropathol. Exp. Neurol. 71, 362-381, 2012. https://doi.org/10.1097/ NEN.0b013e31825018f7

Nonnenmacher M, Weber T, Gene Ther. 19, 649-658, 2012. https:// doi.org/10.1038/gt.2012.6

Padurariu M, Ciobica A, Mavroudis I, Fotiou D, Baloyannis S, Psychiatr. Danub. 24, 152-158, 2012.

Platt TL, Reeves VL, Murphy MP, Biochim. Biophys. Acta. 1832, 1437-1448, 2013. https://doi.org/10.1016/j. bbadis.2013.04.017
Ramirez JJ, Poulton WE, Knelson E, Barton C, King MA, Klein RL, Behav. Brain Res. 216, 332-340, 2011. https://doi. org/10.1016/j.bbr.2010.08.013

Salegio EA, Samaranch L, Kells AP, Mittermeyer G, San Sebastian W, Zhou S, Beyer J, Forsayeth J, Bankiewicz KS, Gene Ther. 20, 348-352, 2013. https://doi.org/10.1038/gt.2012.27

Sebastian WS, Samaranch L, Heller G, Kells AP, Bringas J, Pivirotto P, Forsayeth J, Bankiewicz KS, Gene Ther. 20, 1178-1183, 2013. https://doi.org/10.1038/gt.2013.48

Selkoe DJ, Cold Spring Harb. Perspect. Biol. 3, 2011.

Shevtsova Z, Malik JM, Michel U, Bähr M, Kügler S, Exp. Physiol. 90, 53-59, 2005. https://doi.org/10.1113/ expphysiol.2004.028159

Shineman DW, Basi GS, Bizon JL, Colton CA, Greenberg BD, Hollister BA, Lincecum J, Leblanc GG, Lee LB, Luo F, Morgan D, Morse I, Refolo LM, Riddell DR, ScearceLevie K, Sweeney P, Yrjänheikki J, Fillit HM, Alzheimers Res. Ther. 3, 28, 2011. https://doi.org/10.1186/ alzrt90

Siman R, Lin YG, Malthankar-Phatak G, Dong Y, J. Neuropathol. Exp. Neurol. 72, 1062-1071, 2013. https://doi.org/10.1097/ NEN.0000000000000006

Simmons D, Nature Education 1, 2008.

Summerford C, Samulski RJ, J. Virol. 72(2), 1438-145, 1998.

Tackenberg C, Brandt R, J. Neurosci. 29, 14439-14450, 2009. https:// doi.org/10.1523/JNEUROSCI.3590-09.2009

van Vliet KM, Blouin V, Brument N, Agbandje-McKenna M, Snyder RO, Methods Mol. Biol. 437, 51-91, 2008. https://doi. org/10.1007/978-1-59745-210-6 2

Walters RW, Yi SM, Keshavjee S, Brown KE, Welsh MJ, Chiorini JA, Zabner J, J. Biol. Chem. 276(23), 20610-20616, 2001. https://doi.org/10.1074/jbc.M101559200

Wu Z, Asokan A, Samulski RJ, Mol. Ther .14,316-327, 2006. https:// doi.org/10.1016/j.ymthe.2006.05.009

Xiao W, Chirmule N, Berta SC, McCullough B, Gao G, Wilson JM, J. Virol. 73, 3994-4003, 1999.

Yang S, Cacquevel M, Saksida LM, Bussey TJ, Schneider BL, Aebischer P, Melani R, Pizzorusso T, Fawcett JW, Spillantini MG, Exp. Neurol. 265, 48-58, 2015. https://doi. org/10.1016/j.expneurol.2014.11.013

Zilka N, Filipcik P, Koson P, Fialova L, Skrabana R, Zilkova M, Rolkova G, Kontsekova E, Novak M, FEBS let. 380, 3582-3588, 2006.

Zincarelli C, Soltys S, Rengo G, Rabinowitz JE, Mol. Ther. 16, 1073-1080, 2008. https://doi.org/10.1038/mt.2008.76 